\title{
The Teaching of Financial Services Regulation: A Contextual View
}

\author{
John. A. Consiglio ${ }^{1}$ \\ ${ }^{1}$ Department of Banking \& Finance, Faculty of Economics, Management \& Accountancy, The University of Malta, \\ Malta \\ Correspondence: John. A. Consiglio, Department of Banking \& Finance, Faculty of Economics, Management \& \\ Accountancy, The University of Malta, Malta.
}

Received: October 23, 2015

Accepted: November 24, 2015

Online Published: April 14, 2016

doi:10.5430/ijfr.v7n2p214

URL: http://dx.doi.org/10.5430/ijfr.v7n2p214

\begin{abstract}
This paper discusses issues and developments that relate to the teaching of bank regulation in tertiary institutions. It considers how course content, teaching texts, and methodology, can become subject to issues like specific, historical, and jurisdictional, cultures and contexts for the discipline. It considers how economic and political approaches impact such teaching. How banking regulations tools are used, and course structures are built, are matters which impinge on the type of trained personnel who later eventually leave academia and end up working on regulatory or compliance matters.
\end{abstract}

Keywords: regulation, financial services regulation, bank regulation, teaching bank regulation

\section{Introduction}

This paper seeks to provide a discussion of various themes relating to what, in the business faculties or institutes of many modern tertiary education institutions, and, more particularly, departments focussing on the teaching of financial services, has become a very important academic discipline in its own right: viz the teaching of, and research on, financial services regulation.

As with many areas that come under financial services, there is a historic background that had its effect or, even, conceptually non-effect, on the teaching of financial services regulation, and we briefly look at that aspect in both an international and purely local context.

In a very broad sense it can be said that financial services institutions were late in fully appreciating that their environment was, so to speak, "being set up" for them by many outside forces: conflicts, politics, society, the law, even the economy itself, not to of course fail to mention the many bank and other financial institution crises. It is therefore correct to see the banks as having for long been (some would say blissfully!) unaware of what was evolving for them as we moved into the post-eighteenth century era. When regulation was, so to speak, "born" - and it is in reality hard to pinpoint when that was the case in many countries - it remained for so long as something happening out there, and perhaps in those times even not something to fret too much over. We consider this aspect in the first part of this paper.

Besides examining some of the theories and developments that have had an impact on the teaching of financial services regulation in tertiary education institutions over recent years, and looking at what has impacted on course contents, at what we are doing now, and what we may expect going into the future, we also try to deal with the often intricate, and possibly still undecided, love-hate (or even lukewarm) relationship between the regulatory and legal worlds, and we consider to what extent the teaching of the two disciplines, i.e. bank regulation and law, differs. The tools and methodologies for the teaching of banking regulation are finally emerging as a topic for research and discussion, and this paper tries to make a contribution, albeit small, in that direction. As we shall see it is indeed more than just an issue of printed texts about modernity's recurrent financial crises.

\section{Did the Banks Help the Discipline?}

Some UK banking historians quote 1866 as being the date when the first recorded bank collapse occurred there. This was the case of Overend Gurney Bank, and, in true contagion or domino fashion, it was a failure that brought down dozens of other banks, and plunged the economy into a crisis. (Note 1) Twentyfour years later, in 1890, Barings Bank suffered a similar meltdown, but most of us are of course knowledgeable about the more notorious 1995 failure 
of that same bank, brought about by Nick Leeson's famous gambles on the SIMEX. Between 1980 and 2003 some 140 countries experienced significant banking sector problems (that is some $75 \%$ of the IMF's membership), and we all know that since then bank failures have certainly not abated.

This scenario strikes me as having, over many long years, been the basic underlying background for a lot of the teaching that, in the business faculties and particularly in the banking departments of many tertiary institutions, goes on of financial services sector regulation. When we engage our students into the subject we often, and sometimes inevitably, end up giving them set doses of:

- The regulation, deregulation, reregulation, overregulation, under regulation, and regulatory fatigue cocktail (what Eric Gerding's book presents as the "regularity instability hypothesis") (Note 2);

- Current or contemporary materials about laws, directives, regulatory bodies' own domestic, or international, structures and regulations;

- Possibly past, or evolving, notions about soft law;

- Regulatory institution change (e.g. the single regulator in a jurisdiction debate), now also at pan-EU inspiration levels;

- Licensing, corporate governance, ownership and affiliation, and capital adequacy (with much of and about the Basle process thown in);

and, perhaps inevitably,

- A necessary dose of required reading about the details and development of many individual institutional crises. (Note 3)

Because no teaching ever takes place in any environmental vacuum (social, political, cultural, and what not), a good place to start is by acknowledging, especially in the case of the microstate of Malta here often referred to for examples, that it is only by default of the banks themselves that the whole thematic of bank regulation, as a separate study and discipline on its own, one to be taught and absorbed, came to the fore. As part of a 42-year-plus banking career I had the experience of a five-year spell where I was in charge of Barclays Bank's staff training centre in Malta, and what then (i.e. in the mid-1960s) clearly came down from the top in terms of direction on what course content had to be, well this never ever included the making of bank staff trainees aware of the truth that all course content taught (in tailored-just-for-the-bank's-needs courses on accounts, forex, bills, credits, advances, branch management, etc) never did these have to consider the contextual reality that from out there - i.e. from the outside of the banks - there was, in term of the single reality of the Rule of Law, an environment that regulated whatever was taught in terms of content, procedures to be followed, etc, and why.

So that was the early reality here in Malta. Within the banks ours was an environment that trained bank employees yes, but never really considered outreaching, or interacting, with the evolving greater external environment. (One is led to hypothesise that Barclays Bank, essentially a colonial bank in pure historic terms, had a one-size-fits-all training model for all its territories.) But such environment had and has, as we all know, a life of its own. The economy, the law, the society, the politics of a country, even any bank's own customers, all of these evolve a dynamic of their own, one that banks ignore at their peril. This dichotomy of institutions being brave, and innovative, amongst Maltese businesses in conceiving and appreciating the value of internal staff training, but then not ever linking or including into their own internal content any awareness of what in the environment was happening to regulate that internal context, must now, a posterior, come to be recognised as an element, one of failure, in the historiography of Maltese banking, even if many gave scant importance to it.

The local institutional environment to which I am here referring is that related to the post late-1950s. My research into periods before those times suggests that the terms "financial services regulation" were practically inexistent, and never previously used. For example, even the term "regulation", on its own, is inexistent in the old legal history text of Judge Dott. Paolo de Bono of 1897. (Note 4) And, closer to our times, even the writings of Malta's legal historian, Prof. Hugh W. Harding, again do not ever highlight "regulation", let alone "financial services regulation", as ever being of specific relevance.

Many of us who come to the teaching of bank regulation at some point or other of our lives must, one feels, admit that we do so with a particular luggage and set of biases. Some of us could be practising bankers who, at some stage of our careers would have done work in legal, or internal audit, or even compliance departments. Others may have spent years working full-time with, or consulting for, regulatory agencies or authorities, or even important central banks. Others still would simply have been lawyers bitten by the bug, i.e. keenly aware of the importance of 
understanding the law within the larger frameworks of financial policy and social evolution, and wanting to teach all about it. My own time working for financial institutions, and seconded to government corporations, was entirely on the business and strategic side, not within the offices of legal counsel or compliance managers. Perhaps that was a blessing in disguise, because, albeit from a distance, i now tend to think of legal and regulatory practice as being roles that should serve the long term strategic prosperity of society and banking businesses as such, whose long term prosperity necessarily involves both stability and the addition of value for both shareholders and the communities in which they operate. I return to this theme later.

Another example of the environmental luggage, or bias, with which the teaching of bank regulation is often saddled is that which Baxter (2014) calls "the problem, or reality, of steady 'formalisation' of bank regulation". In the days before about 1980-1990 - (in the case of the US this was around and even before the S \& L (savings and loans) crisis) - bank regulation operated among members of the so-called "club" and according to external beaurocratic discretion, in which the mere hint of regulatory disapproval was generally enough to bring a bank into compliance. With the excesses of the S \& L crisis the US Congress reacted angrily and formalised many sanctions. Yet, paradoxically, this led to less cooperation and increased demands for "due process". At the same time the process had the effect of driving bank regulation into the realm of law. Perhaps it is only in the US that situations such as this, or similar to it, create the perception why the subject is so recent a topic (should we call it a "phenomenon"?) in law schools or faculties. Before events such as these it was as if banking regulation was within the realm of macroeconomists who often seem to me to use language any way they want to and for whom the structures and procedures of the law are inimical.

\section{The Teaching of Regulation and the Legal Profession}

The nexus between the study of regulation on the one hand, and the legal profession on the other should, speaking idealistically, start from reciprocal respect, and total study and absorption, with each other's important roles. I posit here some brief considerations that go beyond that. I honestly worry when I hear so many young freshmen moving into the Faculty of Law saying that their only objective for after graduation is to "work in financial services". Not for them, (as the Italians would say) the necessary "farsi le ossa in tribunale" (Italian), i.e. developing one's legal backbone in a court of law. Not for them the importance of understanding the law primarily within the larger frameworks of civil or commercial (or criminal) law reasoned litigation, or even of national and/or international financial policy for financial services. Also, with this writing taking place at a time when the European Parliament's decisions, often sourced in the European Banking Union's project, is filtering down into member-states' transposition processes, one even has to query how much - especially in smaller states - such parliaments contain the absolutely needed financial services regulatory sector experience, knowledge, competence, and this even with many lawyers being members of parliaments.

Some would hold that the role of lawyers is simply to serve the immediate ends of businesses that are their clients. By contrast (but not necessarily on the contrary) I take the view that some among the legal profession, whether external or in-house lawyers, sometimes submit far too greatly to the will of business executives, or owners, without asserting independent leadership where the long-term interests of the financial institutions, and their shareholders, and their customers, really demand such exercise of independence. The truth is that quite a number of financial lawyers have sometimes allowed themselves to become too much of a service industry, and appear to have abandoned their roles as a source of wise counsel. Indeed "general counsel" has often become "general facilitator" and a service rather than a professional role.

And so the teaching of banking regulation should really have as a paramount underlying theme the inculcation in students of an understanding, a particular type of mindset, which is much more concerned with the whys than the whats. When we as teachers of banking regulation spend a number of lectures dissecting and discussing, for example, Michael Moran's (1986) seminal writings on the public interest, administration, instrumental, and cultural theories of regulation( Note 5), and changes in regulation - with particular reference to the case of financial markets - our hope is that this will encourage students not only to think strategically (some history of the Politics of Regulation, vide e.g. Francis (1993), Haines (2011), and to a lesser extent Stiglitz (2011) helps) but also to recognise and understand both public and private long-term interests. In reality this may very much sound like asking a lot from both banking students and future lawyers, because, soon after some time in their new professions, impatient executives are seldom willing to listen to a sermon on the virtues of constraints which they would very often be trying to avoid or werk around. But if we, as teachers or academics, do not persist in this effort then we might as well consign our students to roles not significantly different to those of marketers, and human resources personnel (with all due respects to colleagues teaching those other specific roles, and indeed the professionals practising them). 
In Europe, depending on the ECTS spread of courses, different universities are today teaching banking regulation with an eye on both the domestic and international components of the discipline. This is not always the case outside our continent. Colleagues in Hong Kong and Australia tell me that they have more leeway in terms of both choice of content, and time spread available to them for teaching it. So, indeed, a course programme there could even in some institutions extend to years one, two, and three of a full degree course. Compare, inter alia, such teaching situations where the subject is indeed just beginning to find its place. Such is the situation, for example, in Malta's College of Arts, Science \& Technology (MCAST), where, in their Institute of Business \& Commerce, in the second year of their Level 5 Higher Diploma in Financial services course, (a course which actually only started being given in October 2014), this area of studies is not taught at all as a separate credit area of studies, but it is rather thrown in and mixed with other financial services subjects: a situation which inevitably begs the question of "isn't a little knowledge always a dangerous thing?" (Note 6).

In some US universities quite a different situation applies. Some academics hold that it is only in theory that local domestic components of banking regulation courses are easy to build up. In the case of Malta the structuring of this part can be temptingly made to look as a pot pourri of the Malta Financial Services Authorities (MFSA)'s - and other local regulators' (Note 7) - underpinning laws, and the role, structure, and operations, of local financial intermediaries' roles and operations, and of other local financial services law generally (Note 8). That would be dangerously close to failing to give students a feel, a realisation, of many other realities that exist even in a local context: themes like e.g. how regulatory capture operates in Malta, the on-site/off-site regulation dichotomy, capital adequacy considerations, and others; and all, yes, again in our own specific cultural context.

And so, too, the teaching of banking regulation in separate courses, viz domestic banking regulation and international banking regulation, cannot not be, on one hand, an attractive proposition. Aids and materials can - if one is keen enough to make it a lifetime interest by constantly reviewing taught content - these can be put over sensibly researched, brought together, and delivered successfully to both under and post graduate courses. And, of course on the other hnnd making it absolutely clear to students that they can only become outstanding students in this discipline if they accept the fact that they have to become reading gluttons.

Lawrence Baxter, who teaches this discipline at Duke University School of Law in Durham, North Carolina, is one exponent of the opposite position, with regards to this notion of teaching domestic and international banking regulation in separate courses. His is a teaching experience that has gone through several very absorbing facets. When for example, he structured and started teaching a very focussed course called "Big Bank Regulation" he ran into problems from various fronts. For example: not enough student demand, or demand from certain sources for more specialised courses and which often became hard to change, or some colleagues' cold reactions because they did not teach courses across both the domestic and international divides, and even examples of snobbing off simply because some courses did not develop business dynamics more than is traditional for law courses.

To a certain extent one cannot but agree with him that it is probably artificial to nowadays separate domestic and international banking regulation. As the full impact of the new EU regulatory setup - essentially the Banking Union's operations through its ESMA, EBA and EIOPA structures (Note 9) - forcibly sinks into the operations of EU markets (including those in smaller states like Cyprus, and Malta), one will come to see that a good component of any course in international banking regulation will, anyway, find its way onto any domestic regulation course.

One can here posit a couple of teasing questions:

- Firstly how can one possibly teach domestic regulation without recognising that the operations of large banks are in most cases transnational, and, in many other cases indeed global: that in fact such banks are either multinational or international? Basel is indeed integral to domestic bank regulation, while the actions and recommendations of the Financial Stability Board, the G20, and other international institutions, have a greater impact (acknowledged or not) on the shape of domestic regulation, be it through rules or agency decisions

- And, secondly, how can any faculty of laws sell as a "Masters course in financial services" a course which would, for example, be built to an extent of, say, some eighty percent of lectures on local law, and only the rest as really having much to do with either international banking or practical in-house financial services work practices. i.e. practical banking (viz the bit done with real life customers and real life banking products)? Shouldn't such a course really come to be renamed as an "MA in Financial Services Law"?

It is interesting to see how, at the University of Wales, the teaching of bank regulation is not essentially focused on the pure discipline per se. Professor John Ashton teaches a course on "Financial Crises and Regulation"; Professor Sharon Ward focuses very much on compliance in her course on "Financial Services Compliance"; and Professor Bob Souster teaches a course called "Professional Ethics and Regulation". In all cases therefore specific topics or 
areas (crises, compliance, ethics, etc) are the actual hangers on to which the many basic regulation clothes are hung. In the specific case of Bob Souster's course the text used is, again, significantly titled "Professionalism, Regulation, and Ethics", but, as said, regulation is only 25 to $30 \%$ of the total module, and certainly not country-specific. The bulk of this course's content covers in fact ethical and professional behaviour, self-regulation, rules-based vs principles-based regulation, corporate governance, and risk management.

It is important to note that in both Bob Souster's course at Wales, and in Marcel Cassar's course on "Financial Regulation" in the Faculty of Laws at the University of Malta, it is that part of the market which consists of people who are already graduates in law, accounting, banking, or economics, which support it. Cassar's course is not focused on the principles of law, or on specific rules and regulations, but much more on considerations pertaining to financial management and behaviour. The emphasis is on a strong message about inherent risks within the banking firm, about corporate governance, politics, and appetite and tolerance of risk, rather than on what is externally, and environmentally, being pushed into, and imposed upon, the firm. This particular financial regulation course is in fact a strong purveyor of the message that the best form of regulation is that which starts within the banking firm itself, and is embedded in the ethos and values of the company. "No amount of laws and rules can ever replace those values of prudence which underpin the trust that the bank must enjoy," Cassar correctly and emphatically holds. Keen movie watchers could do no worse than quote films like "The Enron Affair", "Margin Call", and "Rogue Trader" as ideal illustrations of how it should all not be done.

Significantly Cassar uses no particular text-book, but rather sources and materials which are tailored to particular topics or lectures, and, given the limited 30 hours of lecturing that his course covers, he readily recognises that it can only give a small taste for the wider problematic which in fact is banking regulation. (Note 10) By slight analogy, again at the University of Wales there is a compulsory course module in the Chartered MBA programme, called Financial Institutions Risk Management (FIRM), which is run by our colleague Prof. Ted Gardener, and where the pedagogical underscoring focus (especially now after the new Senior Persons Regime in the UK) is, in a way, similar to Cassar's. Here much emphasis is placed on the integration of ethics, and personal and institutional responsibility and accountability. The main targeted objective is that of integrating bank regulation of risk into a wider macro environment of deregulation of bank structure and conduct rules. (Note 11)

The teaching of bank regulation will therefore necessarily differ substantially between institutions and across faculties. How faculty deans look at the importance, or otherwise, of the subject will impact substantially on the output quality of students. Is the area considered of a sine qua non importance, to the point that the subject is given a compulsory, and not elective, area of studies status? And how many hours of teacher-student contact? And what is the predominant method of teaching it? The formal lecture? The case study approach? The rigid familiarity-with-the-law approach? Students' presentations as a basis for discussion? Or, even, the simulation approach? Insofar as pure legal teaching is concerned the latter is currently being described as a pedagogically valuable and practical tool for teaching modern law curricula, and it is claimed (e.g. Strevens et al (2014) that this form of experiential and problem-based learning enables students to integrate the 'classroom' experience with the real world experiences that they will encounter in their professional lives.

Answers to questions such as these will determine whether students get a small or larger taste of what in reality is the very wide area falling within this special area of financial studies. And eventual quality will of course also be very much dependent on whether one is teaching young undergraduates, or mature (older aged) students. With a clss of the latter, where many would probably already be graduates in, say, law, accounting, banking, or economics, one can better surmount the problems of lectures probably, and necessarily, only serving to give a mere taste of the subject.

With indeed this time factor having already been the case even as much as fifteen years or, say, two decades ago, one can only just imagine how even truer this is the situation nowadays. Inevitably the topic will have to eschew delivery from pure perspectives of law, rules, or regulations, and move instead to a delivery from the angles of financial management and behaviourial considerations. The stronger messages to be imparted would be those concerning risks in the banking firm, the risk management environment, corporate governance, policies and appetite or tolerance of risk. Indeed the good teacher will be emphasising that the best form of regulation is that which starts within the banking firm itself and is embedded in the ethos and values of the company. No amount of laws and rules can ever replace those values of prudence which underpin the trust that every bank must enjoy. (Note 12)

\section{The Problem of Teaching Texts and Contexts}

Always an important issue when discussing the teaching of banking regulation is the issue of texts. Let me for the moment put aside the fact that academics are these days veritably inundated with constantly being published new texts about what, either the writers or the blurbs hold, are the lessons that we should all be teaching our students to memorise, or at least absorb, from the post-Lehman crisis world. That, I hold, should only be one part of the range of 
tools which we as teachers should be using. It is in reality only a small number of writers of such texts who really went to the trouble of updating their casebooks after important legal developments or events, some indeed not necessarily short-lived. In the US Broome and Markham (2010) performed a Herculean task of updating their excellent casebook after the passage of Dodd-Frank. (Note 13) But one is still left somewhat disenchanted with the restrictedly casebook method of teaching financial regulation, particularly now that the field has become so dynamic when compared to what it was twenty years ago when I first started to teach the discipline.

The lawyers of course will rightly say that there have been so many decisions, so many well crafted judicial opinions (e.g. should we here in Malta be considering as such the 2014 historical Constitutional Court decision in the National Bank of Malta case?) that regulation students cannot remain aloof of what, the lawyers would hold, is the important mix and interaction of public policy, agency positioning, and industry advocacy. Yes, these all produce important points but still, I would posit, with the passage of time an evanescent level of inflection. Forcing a class to understand the larger evolving picture through the probably purely episodic vignettes, and often procedural contortions, of cases that make their way to and through the courts, seems to me to distort the overall regulatory discipline, or picture, in ways that are not ideal when one is trying one's best to lay down a long-lasting framework, and the type of mindset to which I have already made reference.

In October of 2008 Heidi M. Schooner and Michael Taylor produced, again in the US, an excellent text that is full of materials which can be used on both domestic and international regulation courses, and, I feel, in universities probably everywhere. Even as I find myself playing around with this book, alongside those by Haines, and by MacNeil and O'Brien (Note 14), for use of some of their materials, I always feel that these all comfortably lend themselves to my own purely personal framework when teaching this subject to final year banking students. But, that said and done, the inquisitive teacher will still jealously protect his academic liberty to vary lecture content from year to year. My own personal course content is comfortably favoured by the fact that, at this stage of their university undergraduate studies, our students would have become suitably and comfortably familiar with banking in its "modern" forms (Note 15), with the notions of risk in bank financial management, with contagion and moral hazard, with "too big to fail" (or is it "to jail"!?) issues, and other vital thematic. And that all allows one a lot of leeway and flexibility to vary content and topics, with the coverage effectively becoming extensive and, I would add, probably also biased towards the international side of banking. (Vide some of my regular lecture topics in Appendix One to this paper).

\section{Regulation of Teachers' Ideals}

As teachers or lecturers we all however probably realise that texts and course contents are of course motivated with a noble purpose: in general terms that of producing persons who, once they would have left the heights, and excitement, of university life, become valid and welcomed contributors to our countries' financial services systems, to our countries' businesses in this sector. Perhaps we try to best encapsulate our efforts in this direction through what we describe as 'learning outcomes'. In general terms they are described as us aiming that students completing our courses will emerge with a level of understanding of the approaches and basic concepts of financial services regulation, and with a level of knowledge of practical developments in regulatory practices, and how these effect market practitioners in their daily work.

One would here be justified in saying that the litmus test of the success, or otherwise, of our daily grind as teachers is to be measured by how much our "products" - i.e. our graduates, even our postgrads and researchers - satisfy the expectations of employers (the financial institutions) out there in the market. And these employers are of course by no means homogeneous in terms of what they do, their internal structures, indeed the terms of their operating licences, not to linger on what they often (fairly or unfairly) often say they want or expect from us. At this point in time the predominantly received vibe is still in the sense that "one of the great things about Malta is its people's skills....they are perfectly capable of handling the demands of an office" (Mahoney, 2014); or "The financial services sector is one of the most important employers of trained professional staff....here Malta continues to rank as one of the top financial jurisdictions, and is positioned in the top 10 of the World Economic Report Global Conmpetitiveness (WEF) Report *(Lutsch-Emmenegger, 2014). (Note 16) Predominantly employers here, including the major regulator, still seek and manage to employ staff for their regulation needs from the local employment market, and they do it using various methodologies, including local media advertising (vide examples in Appendix Two).

In all probability, in then an even higher and more idealistic mindset, the best teachers of banking regulation would tactfully go well beyond this approach. They would be aware that regulation, as a modernist project or topic, involves the development of processes and styles of enforcement that are argued to ensure ever greater and greater levels of compliance which will minimise risk, or avoid a specified harm. Indeed, there are regulatory successes which we as teachers could profitably identify and promote (Note 17). And yet to many (especially in both the media 
and some of the banks themselves) regulation still often continues to appear as not only the solution, but often also the problem. The immense literature on the subject often appears as a never ending saga of teasing apart the technical, the social, and the political elements that seem absolutely inseparable from the discipline.

\section{Conclusions}

The above exposition of issues related to the teaching of banking regulation will of course be far away from the minds of our graduates when they move out into the real world of finance. It is worrying that very often the last thing that they would be concerned with should be a comprehensive, let alone dynamic, appreciation of the challenges that regulation is required to address. These challenges are indeed diverse, and they encompass political, social, and even actuarial risks. This diversity demonstrates the limits of studying compliance without considering the goals that infused reforms, and of scrutinising reforms without taking into account whether and how compliance occurs.

Regulatory reform cascades from international bodies, from parliaments, from domestic regulatory agencies, and finally makes its presence felt at workplaces. Within the different worksites to which our new graduates go, new infrastructure is often created, routines reconfigured, and records and regularly submitted returns developed (are these factually always needed?.... or in those specific formats?) to demonstrate compliance. In this process they, and we too as their teachers, are thus drawn into the hope that improvements are taking place which could reduce the risk of future disasters. All of this is very much in the vision of Kahn's (1990) "spiral of progress".

But the disasters keep occurring, and it is easy to become fatalistic. This is wrong, and it is equally wrong to assume that there never have been clear examples of where the lessons of disasters were learnt, leading to enhanced and well-designed regulatory regimes and high levels of compliance. Here "Never again" could ring true. Or could it really?....especially when we consider that our new graduates sent out into the heavily regulated financial services working markets will, in most probability, also be facing that other big problem of uneducated investors. This is a big and hot topic of its own, and has come to the fore very much from 2012 onwards. The former Federal Reserve President, Ben Bernanke, cited its benefits for US economic health, the European Insurance and Occupational Pensions Authority (EIOPA) issued a report decrying the lack of national investor education strategies, and the International Organisation of Securities Commissions (IOSCO) has also argued for a common European framework to investor education and formal evaluation processes. (Note 18) And we here hold that it is wrong to think that it is a problem, or situation, which is very far from, or totally unrelated to the matter of banking regulation education as a thematic of its own.

When studying the administrative theories of regulation we are often reminded of Beyer's (1982) comments about the failure of matching tools to problems. And one of the great problems is that of surveillance either not being supported by the regularity and suitability of the intelligence that it needs (i.e. data, info, regularly submitted returns); or surveillance becoming inflexible once it is bound by routine and, in the process exposing regulators to the mercy of ingenious operators. Much intelligence may indeed be redundant, irrational, or even demanded and gathered only for symbolic purposes. But, on the other hand, many serious problems have been created by the failures of acting efficiently, effectively, or (even more seriously) in timely enough fashion, on information gathered.

And so we are, yes, also carrying the responsibility of having to teach our students the problems of coordination and control. The dilemmas which they very quickly come to face at their new workplaces, about making choices between hierarchy, and specialisation, and nitty-gritty technical issues, are often wrongly described as only basic failures. But so far no one has offered an explanation of how we can put together an effective mix of hierarchy and specialisation to tackle several constantly reappearing new technical regulators problems.....thankfully not all of them!

\section{References}

Baxter, L. G. (2014). Capture Nuances in the Contest for Financial Regulation. Wake Forest Law Review, 47, 537-568.

Beyer, S. (1982). Regulation and its Reform. Harvard University Press, Cambridge, Mass.

Francis, J. (1993). The Politics of Regulation. Blackwell, Masachisetts US \& Oxford UK.

Gerding, E. (2013). Law, Bubbles, and Financial Regulation. Routledge, London.

Haines, F. (2011). The Paradox of Regulation. Edward Elgar, UK.

Harding Prof. Hugh W. Notes on the History of Maltese Legislation. Unpublished Notes for Students, Faculty of Law, The University of Malta.

Kahn, A. E. (1990). Deregulation: Looking Backward and Looking Forward. Yale Journal on Regulation, 7, 325-54.

Schooner, H. M., \& Taylor, M. W. (2008). Global Bank Regulation, Principles and Policies. Academic Press, New York. 
Stiglitz, J. (2001). Principles opf Financial Regulation: A Dynamic Portfolio Approach. The World Bank Research OIbserver, 16(1), 1-18.

Vide e.g. Strevens C. et al. (eds) (2014). Legal Education: Simulation in Theory and Practice. Ashgate Publishing, Abingdon, oxford \& US.

\section{Notes}

Note 1. In 1873 Walter Bagehot, then editor of The Economist, wrote about that crisis and used it as basis for a fierce attack on the Bank of England.

Note 2. By 2010 the IMF's latest estimates had put the total cost of the latest (i.e. post-2008) collapse at some US\$ 4 trillions, the vast majority of which could be attributed to systemic failures of corporate, regulatory, and political oversight in the US.

Note 3. Students attending the Banking Regulation course at the University of Malta are currently given a case study list of no less than 20 past bank crises to familiarise themselves with.

Note 4. De Bono \& Judge Paolo. (1897). Sommario della storia della legislazione in Malta" - Cap XVI, 353-378; Cap XVII, 279-328 - (Tipografia del Malta). This total absence of reference to "regulation" in De Bono's important work is also confirmed by Prof. Ray Mangion from the Dept of Legal History, Faculty of Law, The University of Malta.

Note 5. Vide e.g. Moran M. (1986) - "Theories of Regulation and Changes in Regulation: the Case of Financial Markets" - (Political Studies, Vol. XXXIV, pp 185-201). Moran's focus is very much based around four major sets of regulatory theories, viz teleogical (or public interest), cultural, instrumental, and administrative.

Note 6. According to Josef Buttigieg from MCAST's Institute of Business \& Commerce there were 18 students on the $2^{\text {nd }}$ Year of this Level 5 Course, and course content generally follows that inspired by the UK's IFS University College.

Note 7. The Central Bank of Malta, the Malta Stock Exchange, and the Ministry of Finance, must also be considered as part of Malta's finance sector regulatory setup. As in every country they are all jealous of 'their own patches', and in this respect, perhaps, we are not dissimilar to the US where the SEC, the FDIC, the Federal Reserve, the Office for Control of the Currency, the General Accounting Office, and other local federal or state bodies, all view with each other in the overall regulatory scenario.

Note 8. Perhaps the major published text in this context is the 2009 "An Introduction to Maltese Financial Services Law" by Ganado \& Associates (Allied Publications, Valletta).

Note 9. The European Securities Markets Authority; the European Banking Authority; and the European Insurance and Occupational Pensions Authority.

Note 10. Marcel Cassar was First Executive Vice-President and CEO of FIMBank plc, and is now CEO of APS Bank in Malta. APS Bank is a totally Church-owned bank. The conceots here are quoted from his responses on Nov 3, 2014 to this author's questions on the subject.

Note 11. Significantly the text used on this course is Financial Institutions Management: A Risk Management Approach by Anthony Saunders and Marcia Cornett (McGraw-Hill/Irwin).

One notes in this context a significant shift at the University of Wales from former MBA (Banking \& Finance) courses, where these were simply called Bank Financial Management and made use of the US textbook Bank Financial Management in the Financial Services Industry by Joseph F. Sinkey Jr. (Macmillan Publishing, New York \& London).

Note 12. The concepts here are sourced in considerations made to the author by Mr. Marcel Cassar (vide Note 14 above) who also lectures on Banking Regulation in the Faculty of Law at the University of Malta.

Note 13. Broome L.L. \& Markham J.W. (2010) - Regulation of Financial Services Activities: Selected Statutes \& Regulations - (American Casebook Services, West). But even their updating misses out on e.g. the Libor scandal (JP Morgan et al), Credit Suisse (the derivatives cartel), the whistle-blowing about HSBC's Latin American money laundering misdemeanours, etc.

Note 14. Haines F. (2011) - op cit. MacNeil I. \& O’Brien J. (2010) - The Future of Financial Regulation - (Hart Publishing, Oxford and Portland, Oregon). 
Note 15. I.e. the "essential", the "incidental", and he "closely relateds" of banking. For examples: balance sheet structure and P \& L dynamics; how banks can earn (and lose) money; how other sectors fit in; and the conflicting ethics and cultures of modern finance. The issue of "regulation as a modern project" is dealt with by Fiona Haines in The Paradox of Regulation (op cit p.3), and also by Reza Banakar in Law and Regulation in Late Modernity in Law and Society Theory, by Banakar R. \& Travers M. (2013) - (Hart Publishing).

Note 16. "The Business Observer" - Malta, Oct 23, 2014, pp 11, 12.

Note 17. Vide e.g. the experiences of certain jurisdictions such as Australia, Singapore, Canada, and others. The experiences of the Australian regulatory system are particularly important and endlessly fascinating to Australians as well as to those who wonder why the Australian financial system has fared better, on all measures, than most others in developed economies. The statutory language which establishes the mandates of their main relevant agencies (their Australian Securities and Investments Commission (ASIC) and Australian Prudential Regulation Authority (APRA) establishes the key drivers of, for APRA financial safety and systemic stability, and for ASIC market integrity and consumer protection.

Note 18. Financial Times, Nov 4, 2012.

The University of Malta

Department of Banking and Finance

Examples of Bank Regulation Course Topics

- Definition(s) of regulation.

- Regulatory theory groups.

- Regulation in society and politics (what sectorial mechanisms and structures make bank regulation necessary?).

- Soft law, and its impact on bank regulation.

- The economic history background.

- Early warning systems.

- Deregulation; Reregulation; Under-regulation; Over-regulation; Better Regulation; Regulatory Fatigue.

- Regulatory capture (the Kane model).

- The "competent authority concept": Malta Financial Services Authority and other regulators.

- Regulation and international relations.

- International banking growth and regulation.

- Multinationalisation and internationalisation as regulatory backgrounds.

- Obstacles and dangers in international banking business.

- On consumer protection.

- On risks, and corporate governance.

- The roles and operations of financial intermediaries.

- The EU and its regulatory impact (including the European Systemic Risk Board, Committee of European Banking Supervisors, the Single Resolution

Mechanism).

- Home and host country control.

- International banking supervision cooperation.

- Basle: evolution and impacts.

- Key EU Directives and key Malta FS legislation. 
Recruiting of staff for regulation duties in Malta

\section{Appendix Two}

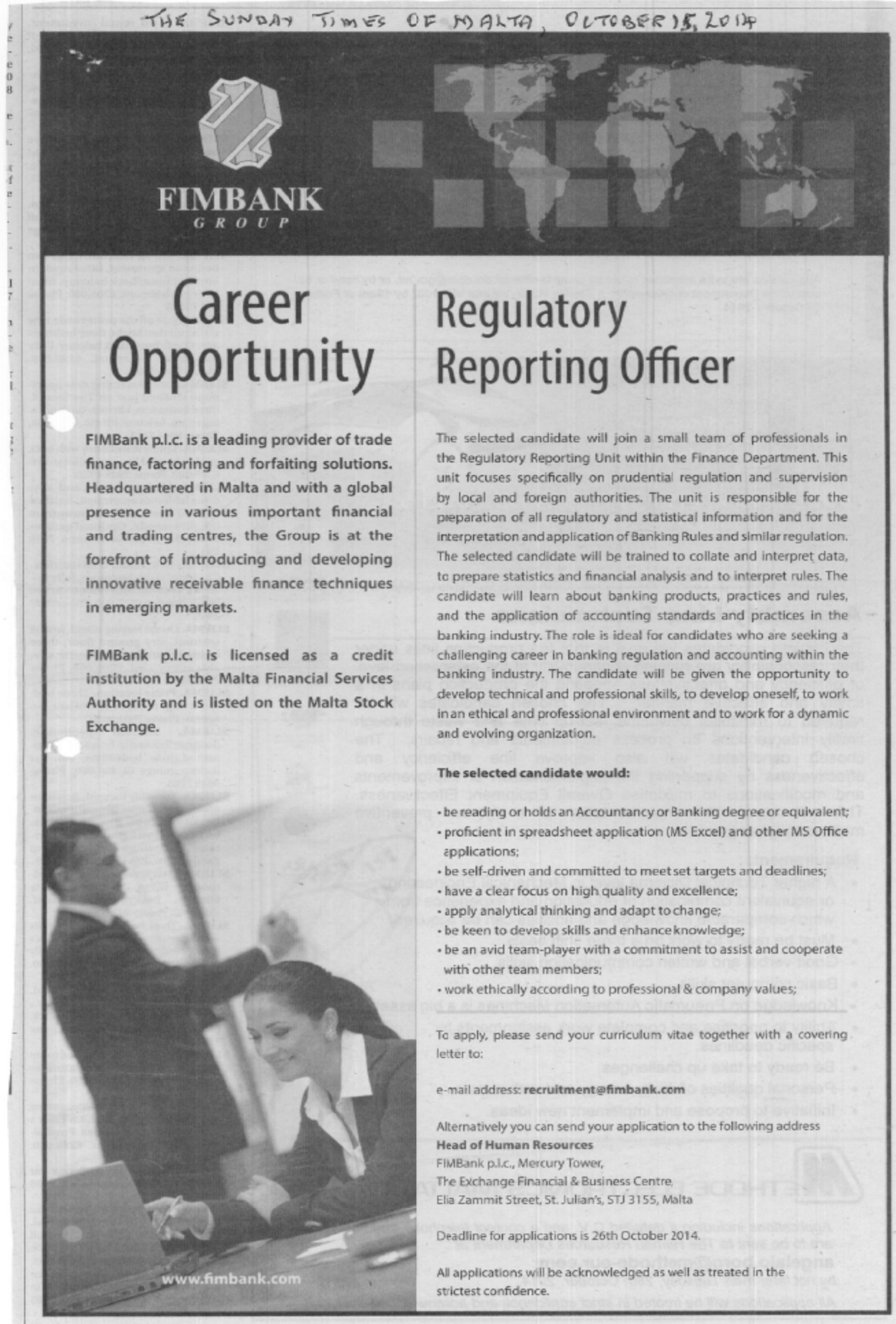

Source: Recruitment advert for Regulatory Reporting Officer by FIMBank Malta, Malta's leading specialist trade finance bank - The Times of Malta, October $15^{\text {th }}, 2014$. 


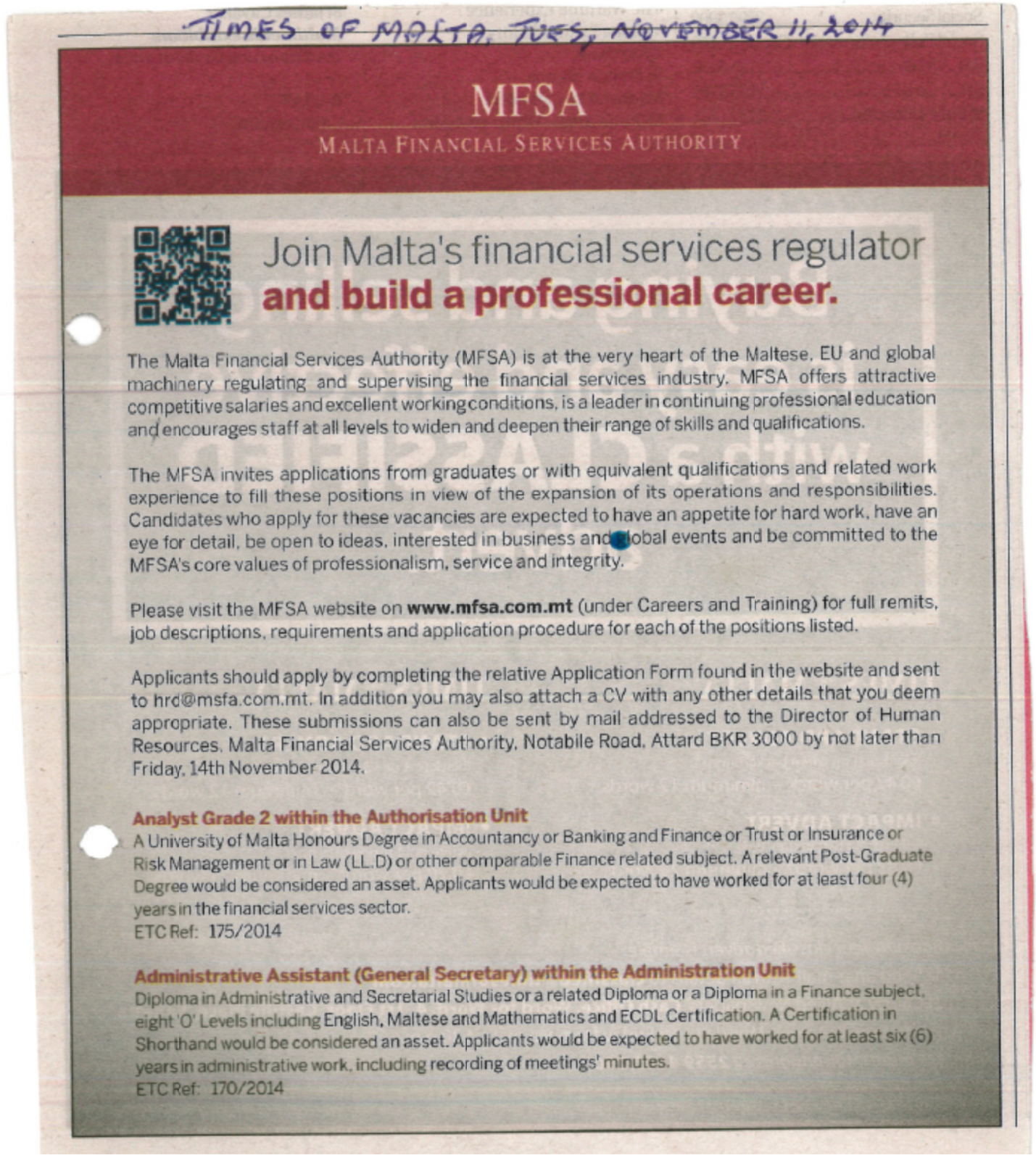

Source: Recruitment advert by Malta's financial services regulator, the Malta Financial Services Regulator - The Sunday Times of Malta, November 11 $1^{\text {th }}, 2014$. 